On the Implementiferoug Gratels near London.

By T. Rtpert Jones, F.R.S., F.G.S., Hon. Memb. Geol. Assoc., \&c.

Introductory.-It is sufficient merely to allude to the plateanlike character which the region now constituting North-west France and South-east England presented at the end of the Pliocene Period, and to the coating of flint gravel* which the more hollow districts received during some part of the Glacial Period from the wear and tear of the Chalk then exposed on cliffs and shoals. We can proceed to consider such explanations as are generally accepted of the agencies that cansed the excavation of the valleys, and their gradual and partial occupation by gravels, sands, and loams of later age. $\dagger$

At one period the land was much higher than at present, the hundred-fathom line around the existing coast being then the shore-line. 'The British rivers then flowed through wider tracts and with greater force in the high grounds, some of those on the east joining the great European river which ran east of the Dogger Bank (then land) into the narrow Scandinarian Channel. Some joined the Somme and the Seine, along what is now the English Channel. The Severn waters went, with some Irish streams, out eastward; and the valley between the Scottish and the Irish highlands drained off to the north-west. Glaciers then occupied the higher grounds, an Arctic climate prevailed for the most part, and the great denudation, begun in Pliocene times, continued until, the sea-level being changed, this area by submergence became an archipelago. Owing to the absence, at that time, of the Gulf Stream, the climate was not greatly ameliorated by the geographical change, before there was a re-emergence of the land. Another communication was thus made with the Continent, and cold winters, at least, set in, until the Gulf Stream, or a warm sea-current was directed to

* See Mr. Trimmer's 'Synoptical Table,' ‘Quart. Journ. Geol. Soc., Vol. ix, (1853), p. 295, for the collocation of this gravel with his "Erratic Tertiaries " of a "Period of Subsidence."

+ Among the chief sources of information on this subject may be mentioned the memoirs by J. Evans, in the 'Archrologia,' Vol. xxxviii, 1860; Vol. xxxix, 1863, and Vol. xl, 1867; and by J. Prestwich in the 'Philosophical Transactions,' Vol. cl, I861; Vol. cliv, 1864; also Chapt. $x \times v$ of Evans's 'Ancient Stone Implements,' \&c., 1872. 
these regions. After some oscillations of level, and the gradual destruction of the isthmus by the tides of the Channel and the North Sea the present topography was established.

During the above-mentioned changes there were at one time the broad expanses of flint gravel, already referred to as existing in Picardy, the "Hampshire Basin," and the "London Basin." This gravel was first accumulated and then spread out in sballow seas and river-mouths by strong currents, storms, and coast-ice; but, rising with one of the emergences, it was excavated into rivervalleys and tidal sea-creeks, and thus divided into many plateaux, with spurs and outliers.* This high-level or plateau gravel is about 400 feet above the sea in some parts of Hampshire and Berkshire. On the general slopes of these plateauxt and on the sides of the valleys various benches and terraces of gravel, with or without brickearths, derived from the removal, washing, and redistribution of the older gravels are traceable at different levels; and in some of these have been found bones of large mammalia, stone implements made by early man, and here and there trunks of trees.

The highest or plateau gravel has not yielded such relics; but stone implements have been collected in large numbers, in terraces at levels of different heights above the sea and the present rivers. Dr. John Evans enumerated the several known instances in Chapter xxii of his 'Ancient Stone Implements of Great Britain,' published in 1872, quoting Boucher de Perthes, Rigollet, Prestwich, Lubbock, Lyell, Wilson, Falconer, Frere, J. Wyatt, E. T. Stevens, W. Greenwell, J. Warren, H. Prigg, J. W. Flower, W. W. Poley, A. H. Lane-Fox (Pitt-Rivers), A. W. Franks, W. Pengelly, F. C. J. Spurrell, C. Le-Neve Foster, T. McK. Hughes, W. Whitaker, W. Boyd Dawkins, J. Brent, T. Codrington, H. P. Blackmore, James Brown, W. F. Tiffin, O. Fisher, A. Tylor, and other observers.

Since that time many useful observations have been made and published; and comprehensive works on Glacial Deposits and 'The Great Ice Age' have been produced by James Geikie and W. Boyd Dawkins. With regard to the London district,

* See 'Proc. Geol. Assoc.,' Vol. vi, 1881, p. 439, \&c., and Vol. viii, 1883, p. 142, and p. 165; also 'Trans. of the Newbury-Jistrict Field Club,' Vol. ii, 1871 , pp. 28 , et seq.

+ These table-lands have gradual inclinations to lower levels, and some parts of these slopes are equivalent to terraces elsewhere. 
General Pitt-Rivers has carefully described the valley-gravels yielding flint-tools at Acton, west of London,* and Messrs. W. G. Smith and J. E. Greenhill, who exhibit so many fine and interesting specimens this evening, have devoted much attention to numerous excavations in the gravel and brickearth of the North-east of London. Mr. W. G. Smith, indeed, has lately produced an elaborate, instructive, and well illustrated memoir on these implement-bearing deposits as exposed in cuttings and diggings, especially within the valleys of the Lea and the Roding at about six miles above their junction with the Thames. $f$ This memoir is a valuable amplification of the brief notice which he supplied of the excursion to Homerton in May, 1883.

Acton.-At Acton the gravels, sands, and brickearths $\$$ remain as more or less irregular deposits, along benches or terraces at different levels, which are looked upon as-1. The low-terrace gravel) at the bends of the present river, rising to 10 or 20 feet above the Ordnance datum (mean-tide at Liverpool). 2. The mid-terrace gravel rising to 20 or 30 feet above the datum, and stretching across the breadth of the lower part of the valley-floor, about $2 \frac{1}{4}$ miles at Turnham Green. 3. The high-terrace gravel, lying on the shoulders of the valley, four miles apart at Turnham Green, at heights of from 50 to 90 and up to 100 feet above the datum. 4. The gravel of the highest level of this district (namely the plateau-gravel), excepting perhaps on a few raised spots, remains only at the north and south margins of the wider containing valley, more than 20 miles apart.

In No. 3 (the high-terrace gravel) numerous flint-chips have been found; and in its lowest portion flint implements, together with remains of Elephas primigenius and the trunk of a pine tree. In No. 2, near its base, are numerous bones of Elephas, Rhinoceros, Equus, Hippopotanus, Bos, Bison, Cervus (3 spp.), and Ursus, showing that many carcases of the native animals were borne down by floods, and their bones deposited in quiet reaches of the river, then at least two miles broad in this locality ; but that (as far as evidence goes) man did not then chip, and

* See 'Quart. Journ. Geol. Soc.,' Vol. xxviii, p. 449, \&c.

$\uparrow$ 'Journ. Anthropol. Instit.' Vol, ziii, p. 357, \&c.

I 'Proc. Geol. Assoc.,' Vol. viii, p. 124, \&c.

$\$$ The wide spread brickearths of the Thames Falley and the loams on top of the platean-gravels are referable to flood-muds and the mud.flats of quiet shallow waters. Some brickearths, however, belong to the "warp" or frost-broken surface-ground. 
shape, and use the flints on the banks of the river just hereabouts, as be did in earlier times, when the river or sea-creek was four miles wide, and when few carcases were floated down to the shoals and shingly banks near or on which man made his implements for hunting, fishing, war, or domestic use. The low-level gravel on and in which the river now runs rests on the London Clay, and is composed of the mixed remnants of former gravel-beds, sorted and resorted, and charged with the relics of later animals and of man's more modern works.

Thus it is erident that after the older plateau-gravel had been formed near the sea-level, at the end of the Great Glacial Period, the broad old Thames Valley was excavated in it by the retreating sea, and by the rain and rivers during the emergence of the land; and the water occupied the valley at various successive levels for long periods, especially marking heights at between 100 and 90 feet, 90 and 50,30 and 20, and between 20 feet and the present level above the Ordnance datum.

Reading. - Further up the river, about 35 miles to the west as the crow flies, the gravel beds on the sides of the Thames Valley at Reading have proved to be of great interest. Here, at Grovelands, the implement-bearing gravel discovered by $\mathrm{Dr}$. Joseph Stevens* fringes the edge of the valley at " 81 feet above the lerel of the river at the junction of the Thames and Kennet," and consists mainly of local material, such as chalkflints, fint pebbles (Tertiary), grit, sand, and comminuted chalk, with quartz, quartzite, and other rock-fragments from older gravels, often rounded and ice-worn. The flint tools occur in more or less distinguishable patches or seams, which are low down in the deposit, and appear to indicate old platforms, where the implements were made. Bones of Elephas and Bos are also present.

At Redlands, also close to Reading, there is a marginal deposit of sand and gravel, largely consisting of re-made local Tertiary beds, "about balf-way up the south slope of the conjoined Thames and Kennet valleys, and 36 feet above the water-level." $\dagger$ Tiro or three artificially-worked tints have come from this gravel, together with bones of Elephas, Rhinoceros, Equus, and Bos, and trunks of pine-

* See his paper on the "Palæolithic Flint Impienents, with Mammalian Remains in the Quaternary Drift at Reading," in the "Transactions of the British Archæological Association,' March, 1881.

t See Mr. Poulton's paper, 'Quart. Journ. Geol. Soc.,' Vol. xxyri, 1880, p. 296, \&c. 
trees. Not far off, close to the junction of the Kennet with the Thames, and rising but little above the present Thames level, another and thick gravel, lying in the valley, has yielded at least one flint tool of the old type, with bones or teeth of Elephas and Equus.*

Thus these three sections of river-drift at Reading indicate three periods when the old water-level was successively at about 80 , 40 , and 30 feet above the present river-level; also that man, with the old mammalia, inhabited the district during the whole time; and that during the period of the first or highest of the three levels man was present on the spot, time after time, manufacturing his stone implementst for bunting, fishing, and other purposes.

By favour of Dr. Stevens we can give the following note of the heights of the upper surfaces of the gravel-pits at Grovelands, Redlands, and New Town, above the sea-level (as defined on the Ordnance-Survey plans), and also above the surface-water at the junction of the rivers Thames and Kennet, determined by $\mathrm{Mr}$. Reed in July, 1880 :-

Above the surface of the water at the junction of the Thames and

\begin{tabular}{|c|c|c|c|c|c|c|c|c|}
\hline \multirow{3}{*}{$\begin{array}{l}\text { Grovelands } \\
\text { Redlands ... }\end{array}$} & \multirow{3}{*}{$\ldots$} & \multirow[b]{2}{*}{$\cdots$} & \multicolumn{3}{|c|}{ Above the Sea-level } & \multicolumn{3}{|c|}{ Kennet. } \\
\hline & & & $\cdots$ & 197 & feet & $\ldots$ & 81 & feet \\
\hline & & $\ldots$ & $\cdots$ & 155 & " & $\ldots$ & 39 & , \\
\hline w Town... & $\cdots$ & ... & ,.. & 146 & " & $\cdots$ & 30 & $"$ \\
\hline of th & vers & ... & $\cdots$ & 115 & ", & & & \\
\hline hurst Con & $\mathrm{n}, \mathrm{n}$ & $\mathrm{R}$ & $\operatorname{lng}$ & 340 & , & ... & 224 & \\
\hline
\end{tabular}

At Grovelands, the gravel is about 15 feet thick; at Redlands, about 10 feet; at New Town it has a thickness of about 20 feet above the river, and evidently extends beneath that level.

At Caversham, also near Reading but on the other side of the river, Dr. Stevens has lately found a beautiful palæolith of the spearhead-shape, $9 \frac{1}{4}$ inches long, besides other specimens, at about 119 feet above the Thames level.

Hampshire and the Isle of Wight.-The relationship of the higher and the lower gravels in the South of England has been

\footnotetext{
* See Dr. J. Stevens's paper above-mentioned. This locality is known as New Town.

+ We need not point ont all the differences between the stone implements of archaic patterns, only chipped into shape, called "Palæolitbs," and those of much later date, which have been ground and polished, or dressed to a nicety by extremely small chjppings, known as "Neoliths."
} 
treated of in a masterly manner by Mr. T. Codrington, C.E., F.G.S., in his memoir " On the Superficial Deposits of the South of Hampshire and the Isle of Wight," "Quart. Journ. Geol. Soc.' Vol. xxvi, p. 528 et seq. He carefully correlates all that Trimmer, F. Forbes, Godwin-Austen, Prestwich, Bristow, Lyell, Evans, and others wrote of these deposits before 1870 ; and particularly notes the several known occurrences of flint implements in the district he so well describes. Besides those in the low-level gravels, some flint tools of archaic patterns have been found at wuch higher levels. Mr. Codrington notes* one on Foreland Point (Isle of Wight), at more than 80 feet, another near Bournemouth at 120 feet, and two on Southampton Common, at 86 feet and 150 feet. These, as well as others to the north of London, are probably, not from the plateau-gravel (that of the bighest level), but from either its modified slopes or the terraces of the highest valley-gravel.

Stoke-Newington and Neighbourhood.-Returning to London and its north-eastern suburbs, we come to Mr. W. G. Smith's chief field of research (see his memoir already alluded to). There are, or have been, gravel-pits and diggings for brickearth on StokeNewington Common (at from 83 feet to 90 feet, and 125 feet abuve the Ordnance datum) ; and these have shown the varying conditions of these Quaternary deposits, and some have yielded old flint implements in abundance, A typical sectiont shows -

5ft.6in. $\left\{\begin{array}{r}\text { 8. Soil, or made ground, with modern and ancient relics, some of } \\ \text { them (neoliths) dating back to prehistoric times. } \\ \text { 7. Brickearth, sandy loam, stony at places, the "warp." } \\ \text { 6. Clayish and stony bed (or pebbly clay), the "trail," irregular } \\ \text { and intruding downwards into No. 5. }\end{array}\right.$
6ft.0in. $\left\{\begin{array}{r}\text { 5. Brickearth, with the "palæolithic floor" at its base. } \\ \text { 3. Sands, various, in thin beds. } \\ \text { 2. Buff sand, with numerous land and river shells, including } \\ \text { Cyrena (Corbicula), Hydrobia, \&c. (See Mr. W. G. Smith's } \\ \text { paper, pp. 368, et seq.) }\end{array}\right.$

1. Gravel, coarse, with large blocks of stone.

In the gravel, No. 1, are rough flints, waterworn pieces (some large) of quartz, quartzite, sandstone, lydite, and granitic rock, with various derived fossils, obtained mostly from the Glacial beds

* Loc. cit., p. 537, 542, and 549.

† 'Proc. Geol. Assoc.,' Vol. viii, p. 128; and 'Journ. Anthrop. Inst.,' Vol. siii, p. 86, pl. 11, fig. 10. 
further north. More or less waterworn flint implements of the old types (palæoliths) are found in this gravel, also rolled bones, teeth, and antlers, and drifted wood. This is known to Mr. W. G. Smith as the old gravel of the Thames and Lea; and he correlates it with a gravel described by Prof. Prestwich in the 'Quart. Jonrn. Geol. Soc.' Vol. xi, 1855, p. 108, as exposed in 1853, at West Hackney, at 60 feet above the level of Trinity high-water mark. This gravel (No. 1) has yielded palæoliths (Mr. W. G. Smith says) between the 50 and 100 feet contour-lines of the Ordnance map, chiefly between those of 70 and 75 feet.

Nos. 2-5 belong to the "Brickearth Series" of the Thames Valley. A similar series is exbibited in Mr. Alfred Tylor's section of the Stoke-Newington Pit, at p. 95, 'Quart. Journ. Geol. Soc.' Vol. xxv, 1869 ; and a comparison of the brickearths and gravels of this district with those at Crayford, lower down on the other side of the Thames, is offered in Mr. A. Tylor's notes and sections in the same paper at pages 90-95. The equivalent Quaternary deposits at Grays and Erith are also treated of and carefully illustrated in the same memoir. See also the important paper by Mr. F. C. J. Spurrell "On the Discovery of Palæolithic Implements at Crayford," and descriptive of the deposits there, "Quart. Journ. Geol. Soc.,' Vol. xxxvi, 1880, p. 544, \&c.

At the base of No. 5, Mr. W. G. Smith has noticed a thin layer of ochreous flint gravel, with waterworn pieces of sandstone, quartzite, lydite, quartz, and chalk, all of rather small size, together with rolled bones, teeth, and antlers, and some drift-wood. This seam is nearly continuous over a considerable area, at somewhat different levels across the valley of the Lea ; and is sometimes repeated at short vertical distances over a limited space. At several places along this particular layer of gravel Mr. W. G. Smith has collected numerous fint flakes and dressed implements of the old types (palæoliths), retaining their original sharp edges uninjured, excepting where this particular implement-bearing gravel, named by him the "palaolithic floor," has been intruded upon and disturbed by the violent agent, whether " moving ice or frozen mud from the north," which ploughed it up, often pushing it into contortions with the associated brickearth.

No. 6. A similar deposit in the Eastern Counties has been described by the Rev. O. Fisher, as the "trail,"* and referred by

- 'Quart. Journ Geol. Soc.,'Vol, xxii, 1866, p. 555, \&c. 'Geol. Mag.' Vol. iv, 1867, pp. 192 et seq., and Vol, v, 1868, p. 147. 
him to the action of land-ice, during the last denudation of the surface, forming pits and furrows and leaving them filled with gravel or gravelly clay. An example of this "trail " has lately been noticed by Mr. John Allen-Brown near Ealing, ("Proc. Geol. Assoc.,' Vol, viii, 1883, pp. 172-181). A useful compendium of published opinions on this glacial formation is given in his interesting paper. According to Mr. A. Tylor this "trail" reaches up to 125 feet above the Ordnance datum in the StokeNewington district.

No. 7 appears to be the "warp," first described by Mr. Trimmer, and treated of by the Rev. O. Fisher, especially in the memoirs and notes above referred to. Mr. W. G. Smith terms this loamy formation "the mud of the trail," and groups it with No. 6 as the "warp and trail," stating that "palæolithic implements and flakes of different ages, and in all stages of abrasion and decomposition, and fixed in the clay at various angles," even upright, are found therein. The "warp" (like the subaërial beds called "head" by Godwin-Austen) has been referred by O. Fisher to the disintegrating effects of the long-continued frost of severe winters on the surface of the ground; and the gradual southward creep of these half-thawed muds and heavily slipping masses of gravel-laden ice could easily bring the palæoliths from higher districts, rubbing and grinding them during the passage. Some appear (Mr. Smith intimates) to have been brought from Amwell at a height of 181 feet, from Ware at 145 feet, Hertford at 132 feet, and Enfield at 129 feet, to be deposited in North-east London at about 85 feet above the Ordnance datum, and at Ealing Dean some have come down from heights, on the north, of 164 feet.

Mr. W. G. Smith considers that the " palæolithic floor," covered with the trail and warp, stretched all across the district, following the slopes of an old valley, in which the Lea formerly flowed at a level of at least 20 feet above the present river; and indeed these beds, he thinks, reached orer the whole of East Middlesex, as far as Hertford and Ware, and down both sides of the Thames from London to the Nore. When these conditions existed early man settled on the sandy banks and gravelly river-flats, fashioning his necessary implements of flint by dexterous chipping ; and abundant traces of his handiwork were buried by flood-shingle and floodmuds, at long or short intervals, until he deserted the marshy valleys of the ancient Thames and its tributaries, driven away, perhaps, by inclement climate, or swept away by rising floods. 
The ground on which he lived and worked was in a great part removed by a denudation reaching down to the present water-level,* certainly 20 feet below him on the Lea; and the alluvium of the present valley, characterized by relics of much later timesneoliths and historic antiquities-must be at least 2,000 years old, judging from the British "Cowey Stakes" set in the Thames to defend a ford against the Romans. To estimate a chronology for the "palæolithic floor" is very difficult; and any calculation we may make at present must be doubtful.

Conclusion.-The Rev. O. Fisher in 1867 calculated ("Geol. Mag.' Vol. iv, p. 195, \&c.), on astronomical data, that possibly upwards of 110,000 years ago there was a period of extensive denudation here, indicated by furrows filled with gravelly and clayish materials which travelled from higher grounds in a plastic frozen state ("trail"), and bringing the surface almost to its present form. Then the climate of North-west Europe became milder and a time of equable seasons lasted for 80,000 years, allowing forests and the mammoth to flourish here. Then the winters seem to have become intensely cold again, giving origin to the "warp;" and probably the reindeer then lived here, about 11,000 years ago. A slight sinking of the land submerged some of the maritime forest-lands, and the Scrobicularian clays corered them. The great mammalia died out in the British area at about this time, some 10,000 years ago, rather later than the date suggested by the result of Prof. Prestwich's researches (see "Lecture on the Antiquity of Man," "Croydon Microscop. Club', April, 1876, p. 32). Lastly, says $O$. Fisher, a succeeding re-emergence of the land, attended by denudation due to increased height, marked the commencement of the "Recent Period," at about 8,000 years ago.

The "Palæolithic Period," older than the "trail," is thus thrown back to relatively early times, perhaps to nearly 200,000 years ago (O. Fisher, op. cit.pp. 198, et seq.); a date broadly in

* The reader's attention is directed to some clear and useful observations by Dr. A. Geikie, in the 'English Illustrated Magazine,' Vol. i (1884), pp. 249,250 , on the glacial accumulations having partly filled and obscured the old river-valleys, and on the amount of work done by the present rivers in cutting some of them ont again. The elaborate memoirs by Mr. Searles Wood, "On the Newer Pliocene Period in England" "Quart. Journ. Geol. Soc.', Vols. xxxri and xxxviii), contain a great mass of valuable information concerning the plateanx, valleys, and rivers of the Southern and Eastern parts of England, and on the glacial phenomena and their results during the oscillations of the land. The numerous maps and sections illustrating the papers will be of great serpice to anyone working at this subject. 
accordance with that arrived at in my Croydon lecture on the "Antiquity of Man," 1876, p. 48.

Who can say what lapse of time separated the makers of the palæoliths now found in the old river-gravel (No. 1), which came from older sites, worn down or flooded out at earlier stages in the history of the valley, from those of Mr. W. G. Smith's "palæolithic floor," lying on the "Brickearth Series" higher up in the section?

It is quite possible that the base of the "high-terrace" gravel at Acton, and the seams of implement-bearing gravel at Grovelands (Reading), may represent the more definitely marked "palæolithic floor" of Stoke Newington; but the deposits at different portions of a large drainage-area can scarcely be correlated with accuracy. At all events, men having the same habits and pursuits occupied the river-banks not only at that early period, but long before!

\section{VISIT TO THE BRITISH MUSEUM (NATURAL HISTORY) DEPARTMENT OF GEOLOGY.}

\section{Saturday, March $15 \mathrm{Th}, 1884$.}

Prementation of an Adpregs to Sir Richard Owen, K.C.B., and Demonstration on Fossil Fishes by Dr. Henty WOODWARD, F.R.S.

The members having assembled in the Lecture-room, the President, in presenting to Sir Richard Owen the following Address from the Association, on the occasion of his retirement from the post of Director-General of the Natural History Departments of the British Museum, said that the members of the Association had deputed him to present the address, and in so doing he might say that in his view no more appropriate place could possibly have been selected for the purpose than the building which he looked upon as a memorial of Sir Richard Owen's constant adrocacy of the claims of natural science to a due recognition from the State. All lovers of natural history felt justly proud of this great institution, and that its several departments were presided over by men so eminent in their several spheres. The Geologists' Association might well, he thought, be congratulated on the fact that so many of the most important positions in the inuseum were held by its members. He might also be permitted, on behalf of the Associa- 